\title{
Pengaruh Kepribadian, Orientasi Kerja Dan Penempatan Pegawai Terhadap Kinerja Pegawai Bank Nagari Cabang Utama Kota Padang
}

\author{
Andry Novrianto \\ Universitas Putra Indonesia YPTK Padang, Indonesia \\ andrynovrianto@upiyptk.ac.id
}

\begin{abstract}
This study was conducted to determine the extent of the influence of personality, work orientation and employee placement on the performance of employees of Bank Nagari Main Branch of Padang City. This type of research is descriptive and causal research with 98 respondents. Test and analysis methods with validity, reliability, multiple linear regression analysis and coefficient of determination tests. In testing the hypothesis for Personality on Employee Performance obtained partially the influence of employee personality has a significant influence on employee loyalty. For testing the Work Orientation variable towards Employee Performance, partially perceived value has a significant effect on Employee Performance. For testing the Employee Placement variable on Employee Performance obtained partially has a significant effect on Employee Performance. With the results of this study it is expected to help the management of Bank Nagari in formulating strategies in improving the performance of employees of Bank Nagari in Padang City Branch.
\end{abstract}

Keywords: Influence of Personality, Work Orientation, Employee Placement, Employee Performance

\section{Pendahuluan}

Perbankan sebagai suatu lembaga keuangan kepercayaan masyarakat yang memegang peranan penting dalam sistem perekonomian, sehingga dapat dikatakan bank merupakan urat nadi dari sistem keuangan yang beraktifitas menerima simpanan dari masyarakat dalam bentuk tabungan, giro, deposito dll, yang kemudian dana yang terkumpul dari masyarakat tersebut disalurkan kembali ke masyarakat dalam bentuk kredit. Sebagai badan usaha yang bergerak dalam bidang jasa, kepercayaan dari semua pihak yang terkait adalah hal yang sangat penting baik, bagi pemilik dan pengelola bank maupun masyarakat sebagai pengguna jasa bank.

Berdasarkan peraturan Daerah Nomor 16 Tahun 2008 tentang pembentukan susunan organisasi dan tata kerja Perusahaan Daerah sebagaimana telah diubah dengan Peraturan Daerah Nomor 14 tahun 2012, kedudukan, tugas pokok, fungsi dan susunan organisasidari Dinas Pendidikan adalah “Unsur Pelaksana Pemerintah Daerah di Bidang Perbankan”.maka Bank Nagari Cabang Pembantu Niaga mempunyai tugas melaksanakan urusan pemerintahan daerah di bidang perbankan serta tugas pembantuan. Untuk melaksanakan tugas sebagaimana dimaksud, Perbankan mempunyai fungsi sebagai perumusan kebijakan teknis di bidang perbankan, penyelenggaraan urusan pemerintah dan pelayanan Umum dibidang Perbankan, pembinaan dan pelaksanaan urusan dibidang perbankan dan pembinaan Unit Pelaksanaan Teknis Perusahaan.

Dari hasil observasi awal dengan pimpinan Bank Nagari Cabang Utama Kota Padang didapatkan fenomena : Pegawai banyak yang datang terlambat, target kerja belum 100\% tercapai, pegawai banyak yang tidak jelas bekerja.

Kepribadian merupakan salah satu faktor penting bagi suatu instansi untuk melihat kinerja karyawannya karena kepribadian seseorang akan menentukan hasil kerjanya sendiri. Kepribadian merupakan latar belakang dari prilaku seseorang.Hal tersebut berarti bahwa kepribadian itu 
menunjukkan prilaku dari sikap-sikap seorang individu untuk dapat berbuat, mengetahui, berpikir dalam sebuah organisasi. Kepribadian biasanya akan tergambar pada kehidupan sehari-hari dari pegawai itu sendiri, bagaimana reaksi atau responya ketika mendapat dan menyelesaikan tugas dari organisasi. Biasanya akan terlihat dalam lingkungan pekerjaan bagaimana cara karyawan bersosial, cara bertutur kata baik terhadap atasan, sesama derajat maupun bawahan

Orientasi kerja dalam sebuah organisasi diberikan agar pegawai mampu mengenal dan beradaptasi dengan organisasi, serta mengetahui dan terampil saat menjalankan tugas dan pekerjaan dari organisasi.Orientasi tersebut biasannya diberikan kepada karyawan baru. Setiap karyawan yang tergabung dalam suatu organisasi memiliki orientasi kerja masing-masing dan kemungkinan besar karyawan satu dan lainnya mempunyai orientasi kerja yang berbeda pula dan apabila orientasi yang dipersiapkannya ini dapat tercapai maka pegawai ini akan merasakan kepuasan kerja dan bekerja dengan maksimal. Orientasi juga berhubugan dengan orang-orang yang akan bekerja sama dengannya. Orientasi pada dasarnya merupakan salah satu komponen proses sosialisasi karyawan baru, yaitu suatu proses penanaman sikap, standar, nilai, dan pola perilaku yang berlaku dalam perusahaan kepada karyawan baru.

Penempatan juga merupakan faktor penting dalam menilai kinerja karyawan. Penempatan adalah suatu proses pemberian tugas kepada tenaga kerja dan dijalankan secara bersama-sama dengan tanggung jawab yang telah diberikan. Salah satu faktor yang mempengaruhi penempatan adalah latar belakang pendidikan karyawan untuk itu, prestasi akademik yang telah dicapai oleh tenaga kerja selama mengikuti jenjang pendidikan harus mendapat pertimbangan dalam penempatan. Ardana, Mujiati dan Utama (2012:82) menyatakan bahwa penempatan SDM adalah suatu proses pemberian tugas dan pekerjaan yang lulus dalam seleksi untuk dilaksanakan secara continue dan wewenang serta tanggung jawab yang melekat sebesar porsi dan komposisi yang ditetapkan serta mampu mempertanggungjawabkan segala risiko yang mungkin terjadi atas tugas dan pekerjaan, wewenang dan tanggung jawab tersebut.

Tabel 1

Absensi Pegawai Bank Nagari Cabang Utama Kota Padang Tahun 2015-2017

Bulan Jumlah Keterangan
pegawai

\begin{tabular}{llll}
\hline Hadir tepat & Terlambat & Alpha & Izin
\end{tabular}

waktu

\begin{tabular}{|c|c|c|c|c|c|c|}
\hline Januari & 152 & 121 & 20 & - & - & 4 \\
\hline Februari & 152 & 130 & 11 & - & 1 & 2 \\
\hline Maret & 152 & 124 & 12 & - & 3 & 6 \\
\hline April & 152 & 120 & 20 & - & 1 & 5 \\
\hline Mei & 152 & 124 & 17 & - & 2 & 3 \\
\hline Juni & 152 & 122 & 18 & - & 2 & 4 \\
\hline Juli & 152 & 124 & 14 & - & 5 & 4 \\
\hline Agustus & 152 & 126 & 16 & - & - & 3 \\
\hline September & 152 & 124 & 14 & - & - & 6 \\
\hline Oktober & 152 & 127 & 17 & - & - & 2 \\
\hline November & 152 & 124 & 16 & - & 3 & 4 \\
\hline Desember & 152 & 121 & 17 & - & 2 & 5 \\
\hline
\end{tabular}

Sumber: data karyawan bank nagari cabang utama kota padang tahun 2015-2017

Dari table 1 dapat dilihat bahwa tingkat kehadiran tepat waktu pegawai cukup tinggi tetapi data pegawai yang terlambat selalu berfluktuasi yang cenderung meningkat dari bulan januari sampai Desember. Walaupun alasan keterlambatan tersebut berbeda- beda. Hal ini disebabkan karena kurang nya kepuasan kerja yang di terima oleh pegawai terhadap perusahaan sehingga mereka tidak mendapatkan apresiasi oleh perusahaan. Hal ini akan pengaruh pada kinerja pegawai dinas peternakan kota Padang yang tidak maksimal karena pada saat pegawai terlambat datang untuk bekerja ke kantor maka pekerjaan dan tanggung jawabnya akan tertunda kinerja yang kurang maksimal akan menyebabkan kerugian besar bagi dinas peternakan kota Padang. Oleh 
karena itu perusahaan arus mencari solusi terhadap masalah yang terjadi yang terjadi didalam perusahaannya. Salah stunya adalah dengan memberikan kepuasan kerja, dukungan organisasi yang layak dan memberikan pengembangan karir yang bagus agar pegawai bisa terpacu untuk bekerja.

Berdasarkan pengamatan penulis dan hasil wawancara dengan pihak Bank Nagari Cabang Utama ada beberapa fenomena dalam kasus ini, seperti : Banyak karyawan yang mengundurkan diri dari pekerjaannya, penempatan Pegawai tidak pas dan Kinerja Karyawan juga turun dari ke tahun membuat banyak pegawai yang Resign dari perkerjaannya

Berdasarkan hal tersebut diatas maka peneliti tertarik melakukan penelitian tentang kinerja karyawan yang secara teoritis mempunyai pengaruh terhadap Kepribadian, orientasi kerja dan Kinerja karyawan pada Bank Nagari Cabang Niaga Kota Padang. Tujuan dari peneliatian ini adalah untuk mengetahui pengaruh secara parsial dan simultan antara kepribadian, orientasi kerja, dan penempatan pegawai terhadap kinerja pegawai pada Bank Nagari Cabang Utama Kota Padang.

Berikut kerangka pemikiran dari penelitian ini dapat dilihat pada gambar dibawah:

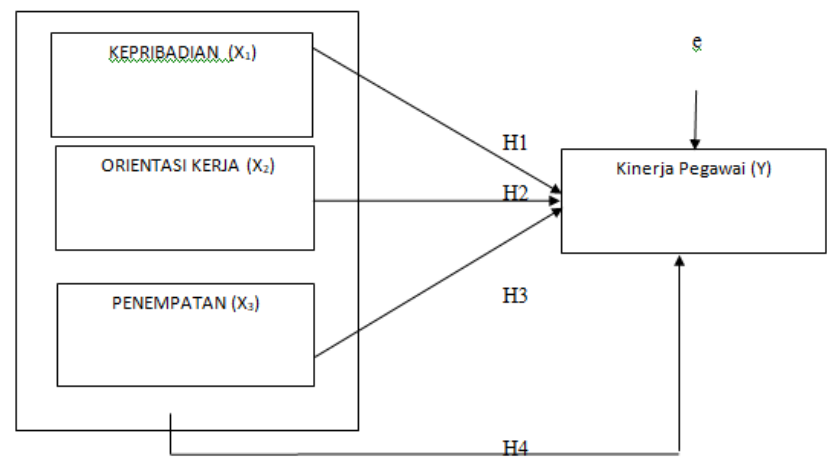

Berdasarkan kerangka pikir tersebut maka dirumuskan hipotesis sebagai berikut :

H1 : Kepribadian berpengaruh secara parsial terhadap kinerja pegawai pada Bank Nagari Cabang Utama Kota Padang.

H2 : Orientasi kerja berpengaruh secara parsial terhadap kinerja pegawai pada Bank Nagari Cabang Utama Kota Padang

H3 : Penempatan pegawai berpengaruh secara parsial terhadap kinerja pegawai pada Bank Nagari Cabang Utama Kota Padang.

H4 : Kepribadian, orientasi kerja, dan penempatan pegawai berpengaruh secara bersama-sama terhadap kinerja pegawai pada Bank Nagari Cabang Utama Kota Padang.

\section{Metodologi Penelitian}

\section{Jenis Penelitian}

Jenis penelitian ini merupakan penelitian deskriptif dan kausal. Menurut Sugiyono (2013: 11) Penelitian diskriptif adalah penelitian yang dilakukan untuk mengetahui nilai variabel mandiri, baik satu variabel atau lebih (independen) tanpa membuat perbandingan, atau menghubungkan dengan variabel yang lain. Menurut Sugiyono, (2013:14) Penelitian kualitatif, data kualitatif adalah data yang berbentuk kata, skema, dan gambar. Menurut Sugiyono (2012: 59) hubungan kausal adalah hubungan yang bersifat sebab akibat. Jadi, disini ada variabel independen (mempengaruhi) dan variabel dependen (dipengaruhi). Hal ini berarti penelitian berfokus pada pengaruh penggunaan media gambar sebagai variabel independen terhadap hasil belajar sebagai variabel dependen. 


\section{Populasi dan Sampel}

Menurut Sugiyono (2016: 80) populasi adalah wilayah generalisasi yang terdiri atas: obyek/subyek yang mempunyai kualitas dan karakteristik tertentu yang ditetapkan oleh peneliti untuk dipelajari dan kemudian ditarik kesimpulannya, berdasarkan data yang diperoleh jumlah populasi adalah seluruh karyawan yang berada di kantor Bank Nagari cabang Utama Padang berjumlah 130 karyawan.

Sampel penelitian ditentukan dengan cara simple random sampling. Menurut Sugiyono (2012: 120) dikatakan simple (sederhana) karena pengambilan sampel dari populasi dilakukan secara acak tanpa memperhatikan strata yang ada dalam populasi. Pengambilan dilakukan dengan cara memberikan kuesioner kepada karyawan Bank Nagari cabang Utama Padang yang ditemui peneliti, maka perhitungan jumlah sampel didasarkan pada rumus formula statistik Slovin sebagai berikut:

$$
\mathrm{n}=\frac{\mathrm{N}}{1+N e^{2}}
$$

Keterangan :

$\mathrm{n}=$ Ukuran Sampel

$\mathrm{N}=$ Ukuran Populasi

$\mathrm{e}=$ keselenggaran ketidaktelitian karena kesalahan pengambilan sampel yang masih dapat di tolerir ( pada penelitian ini digunakan 5\%).

\section{Hasil Dan Pembahasan}

\section{Uji Validitas}

Menurut Ghozali (2012) Uji validitas digunakan untuk mengukur sah/ valid tidak suatu kuesioner, suatu kuesioner dinyatakan valid apabila pertanyaan kuesioner mampu mengungkapkan sesuatu yang diukur oleh kuesioner tersebut, validitas menunjukkan sejauh mana alat pengukur yang digunakan untuk mengukur apa yang diukur.

\section{Uji Reliabilitas}

Menurut Ghozali (2014) mendefinisikan reliabilitas adalah alat untuk mengukur suatu kuesioner yang merupakan indikator dari variabel atau konstruk. Uji reliabilitas dilakukan terhadap item pertanyaan yang dinyatakan valid. Dengan kata lain, reliabilitas menunjukkan konsistensi suatu alat ukur dalam mengukur gejala yang sama.

\section{Analisis Regresi Linear Berganda}

Analisis regresi linier berganda diperlukan guna mengetahui koefisien-koefisien regresi serta signifikansi sehingga dapat dipergunakan untuk menjawab hipotesis. Secara umum formulasi dari regresi linier berganda dapat ditulis sebagai berikut :

$\begin{array}{lll} & \mathbf{Y}=\mathbf{a}+\mathbf{b}_{\mathbf{1}} \mathbf{X}_{\mathbf{1}}+\mathbf{b}_{\mathbf{2}} \mathbf{X}_{\mathbf{2}}+\mathbf{b}_{\mathbf{3}} \mathbf{X}_{\mathbf{3}}+\mathbf{e} \\ \text { Keterangan : } & & \text { Variabel dependent } \text { (kinerja karyawan) } \\ \mathrm{Y} & = & \text { Konstanta } \\ \mathrm{A} & = & \text { Koefisien regresi variabel bebas } \\ \mathrm{b} 1, \mathrm{~b} 2, \mathrm{~b} 3 & = & \text { Variabel independent } \text { (kepemimpinan) } \\ \mathrm{X} 1 & = & \text { Variabel independent } \text { (kompensasi) } \\ \mathrm{X} 2 & = & \text { Variabel independent } \text { (lingkungan kerja fisik) } \\ \mathrm{X} 3 & = & \text { standart error / tingkat kesalahan. }\end{array}$




\section{Uji Parsial (Uji t)}

Tabel 2. Hasil Uji t

\begin{tabular}{|c|c|c|}
\hline Model & $\mathbf{T}$ & Sig. \\
\hline (Constant) & 8,761 & 0,000 \\
\hline Kepribadian & 5,471 & 0,000 \\
\hline Orientasi Kerja & $-3,687$ & 0,000 \\
\hline $\begin{array}{c}\text { Penempatan } \\
\text { Pegawai }\end{array}$ & 2,577 & 0,011 \\
\hline
\end{tabular}

\section{Uji F}

Tabel 3. Hasil Uji F

\begin{tabular}{cc}
\hline $\mathbf{F}$ & Sig. \\
\hline 27,905 &, $000^{\mathrm{b}}$ \\
Sumber: Olahan Data SPSS 20.
\end{tabular}

\section{Uji Koefisien Determinasi $\left(\mathbf{R}^{2}\right)$}

Uji koefisien determinasi digunakan untuk mengukur seberapa jauh kemampuan model dalam menerangkan variasi variabel independen. Nilai koefisien determinasi adalah antara nol atau satu. Hasil pengukuran koefisien determinasi dapat dilihat sebagai berikut:

Tabel 4. Hasil Uji Koefisien Determinasi

Model Summary

\begin{tabular}{llllll} 
Model & R & R Square & Adjusted R Square & $\begin{array}{l}\text { Std. Error of } \\
\text { Estimate }\end{array}$ \\
\hline 1 & $0,683^{\mathrm{a}}$ & 0,466 & 0,449 & 2,605 \\
\hline
\end{tabular}

Sumber: Olahan Data SPSS 20.

Berdasarkan tabel 4 diperoleh angka Adjusted R Square sebesar 0,449 hal ini menunjukkan bahwa sumbangan variabel Kepribadian, Orientasi Kerja, dan Penempatan Pegawai terhadap Kinerja Pegawai sebesar 0,449 atau 44,9\% sedangkan sisanya sebesar 55,1\% di pengaruhi variabel lain.

\section{Hasil dan Pembahasan}

\section{Pengaruh kepribadian terhadap kinerja pegawai}

Secara parsial ada pengaruh positif dan signifikan antara kepribadiani terhadap kinerja.. Dimana terlihat $t_{\text {hitung }} 5,471$ dan $t_{\text {tabel }} 1,984$ dimana $t_{\text {hitung }}$ lebih besar dari $t_{\text {tabel }}(5,471>1,984)$ atau tingkat signifikan < dari alpha 0,05 maka $\mathrm{H}_{\mathrm{o}}$ ditolak dan $\mathrm{H}_{\mathrm{a}}$ diterima. Hasil penelitian ini sejalan dengan Ricky Montolalu (2016) bahwa terdapat hubungan yang signifikan antara kepribadian dengan kinerja pegawai.

\section{Pengaruh orientasi kerja terhadap kinerja pegawai}

Secara parsial ada pengaruh negatif dan signifikan antara orientasi kerja terhadap kinerja. Dimana $t_{\text {hitung }}-3,687$ dan $t_{\text {tabel }} 1,984$ dimana $t_{\text {hitung }}$ lebih kecil dari $t_{\text {tabel }}(-3,687<1,984)$ atau tingkat signifikan lebih kecil dari dari alpha $(0,000<0,05)$ maka $\mathrm{H}_{\mathrm{o}}$ ditolak dan $\mathrm{H}_{\mathrm{a}}$ diterima. Penelitian ini sejalan dengan Ricky Montolalu. (2016) dan Edward S. Maabuat (2016) bahwa terdapat hubungan yang signifikan antara orientasi kerja dengan kinerja pegawai. 


\section{Pengaruh penempatan terhadap kinerja pegawai}

Secara parsial ada pengaruh positif dan signifikan antara penempatan terhadap kinerja. Dimana $\mathrm{t}_{\text {hitung }}$ terlihat $\mathrm{t}_{\text {hitung }} 2,577$ dan $\mathrm{t}_{\text {tabel }} 1,984$ dimana $\mathrm{t}_{\text {hitung }}$ lebih besar dari $\mathrm{t}_{\text {tabel }}(2,577>$ 1,984) atau tingkat signifikan lebih besar dari dari alpha $(0,011<0,05)$ maka $\mathrm{H}_{\mathrm{o}}$ ditolak dan $\mathrm{H}_{\mathrm{a}}$ diterima. Penelitian ini sejalan dengan Ricky Montolalu (2016), Eunike Anggie Pio (2015), Edward S. Maabuat (2016) dan Regina F. Kondoy, Olivia Nelwan (2015) bahwa terdapat hubungan yang signifikan antara penempatan pegawai dengan kinerja pegawai

\section{Pengaruh kepribadian, orientasi kerja, dan penempatan terhadap kinerja pegawai.}

Secara simultan kepribadian, orientasi kerja dan penempatan pegawai berpengaruh positif dan signifikan terhadap kinerja pegawai. Dimana $F_{\text {hitung }}$ lebih besar dari nilai $F_{\text {tabel }}(27,905>2,47)$. Nilai F 6,785 dengan tingkat signifikan 0,000 lebih kecil dari 5\%. Maka diperoleh $\mathrm{H}_{\mathrm{o}}$ ditolak dan $\mathrm{H}_{\mathrm{a}}$ diterima. Penelitian ini sejalan dengan penelitian Ricky Montolalu (2016). Dan Julia Anita (2013) bahwa terdapat pengaruh positif dan signifikan antara Kepribadian, Orientasi Kerja dan Penempatan Pegawai terhadap Kinerja Pegawai

\section{Kesimpulan}

Berdasarkan pada hasil penelitian dan pembahasan tentang pengaruh pelaksanaan komunikasi organisasi, lingkungan kerja, dan pengembangan pegawai terhadap semangat kerja pegawai pada Bank Nagari Cabang Utama Kota Padang.maka peneliti dapat menarik kesimpulan sebagai berikut: Terdapat pengaruh positif dan signifikan antara kepribadian terhadap kinerja karyawan pada Bank Nagari Cabang Utama Kota Padang. Terdapat pengaruh negatif dan signifikan antara orientasi kerja terhadap kinerja karyawan pada Bank Nagari Cabang Utama Kota Padang. Terdapat pengaruh positif dan signifikan antara penempatan terhadap kinerja karyawan pada Bank Nagari Cabang Utama Kota Padang. Secara bersama-sama antara kepribadian, orientasi kerja dan penempatan pegawai berpengaruh positif dan signifikan terhadap kinerja karyawan pada Bank Nagari Cabang Utama Kota Padang. Nilai adjust R Square hal ini menunjukan bahwa sumbangan variabel kepribadian, orientasi kerja, dan penempatan pegawai dan kinerja karyawan ditentukan oleh variabel lain yang tidak dianalisi dalam model pada penelitian ini

\section{DAFTAR PUSTAKA}

Anita, Julia et al. ,'Pengaruh Penempatan dan Beban Kerja Terhadap Motivasi Kerja dan Dampaknya Pada Prestasi Kerja Pegawai Dinas Tenaga Kerja dan Mobilitas Penduduk Aceh," Jurnal Manajemen, ISSN 2302-0199. Fakultas Ekonomi Universitas Syiah Kuala, 2013.

Ardana,K.I, Mujiati. “Manajemen Sumber Daya Manusia," cetakan pertama. Yogyakarta: PT. Graha Ilmu, 2012.

Azra, Azyumardi. "Esei-esei Intelektual Muslim dan Pendidikan Islam," Jakarta: PT. Logos Wacana Ilmu, 2015.

Chung Megginson, Moorhead, "Organization Behavior Development Managerial Skills," Newyork, 2014.

Ferdinand, Augusty,"Structural Equation Modeling dalam Penelitian Manajemen," BP Universitas Diponegoro, Semarang, 2016.

Ghozali. "Aplikasi Analisis Multivariate dengan Program SPSS," Semarang: Badan Penerbit Universitas Diponegoro, 2014.

Hakim ,Arief Rahman,"Pengaruh Kepribadian, Sikap, Dan Kepemimpinan Terhadap Kinerja Kreatif Dalam Organisasi (Studi Pada Organisasi Kreatif Di Kota Semarang),” Jurnal Manajemen, ISSN 2302 0199, Fakultas Ekonomi Universitas Syiah Kuala, 2016. 
Hanggraeni, “ Manajemen Sumber Daya Manusia,” Bogor: Lembaga Penerbit Fakultas Ekonomi Universitas Indonesia, 2013.

Hasibuan, Malayu S.P.,"Manajemen: Dasar, Pengertian, dan Masalah Edisi Revisi," Jakarta: Bumi Aksara, 2009.

Kondoy, Regina F dan Olivia Nelwan,'Pengaruh Kepemimpinan, Budaya Organisasi dan Orientasi Kerja terhadap Kepuasan Kerja pada Karyawan PT. Bank Sulut Div. Umum, Manado," Jurnal EMBA, ISSN 2303-11, Vol.3 No.3 Sept. 2015, Hal.1208-1219. Fakultas Ekonomi dan Bisnis, Jurusan Manajemen Universitas Sam Ratulangi Manado, 2015.

Mahmudi,"Manajemen Kinerja Sektor Publik," Edisi Kedua. Yogyakarta: UPP STIM YKPN, 2015.

Mangkunegara,"Manajemen Sumber daya Manusia Perusahaan," Bandung: PT Remaja Rosdakarya, 2013.

Maabuat, Edward S.,"Pengaruh Kepemimpinan, Orientasi Kerja, dan Budaya Organisasi Terhadap Kinerja Pegawai (STUDI PADA DISPENDA SULUT UPTD TONDANO)," Jurnal EMBA, Vol.16, no, 01, Tahun 2016. Manado: Fakultas Ekonomi dan Bisnis, Jurusan Manajemen Universitas Sam Ratulangi 2016.

Mihalcea, Alexandru,'Leadership, Personality, Job Satisfaction And Job Performance," Journal Social and Behavioral Sciences 127 ( 2014 ) 443 - 447, 2014.

Moeheriono," Pengukuran Kinerja Berbasis Kompetensi," Jakarta: Raja Grafindo Persada, 2013.

Montolalu, Ricky,"Pengaruh Kepribadian, Orientasi Kerja, dan Penempatan Pegawai Terhadap Kinerja Pegawai Pada Dinas Kebudayaan dan Pariwisata Provinsi Sulawesi Utara," Jurnal $E M B A$, ISSN 2303-1174. Manado: Fakultas Ekonomi dan Bisnis, Jurusan Manajemen Universitas Sam Ratulangi, 2016.

Nawawi, Hadari,"Manajemen Sumber Daya Manusia untuk bisnis yang kompetitif," Yogyakarta: Gadjah Mada University Press, 2014.

Pasolong,"TeoriAdministrasi Publik," Bandung: Alfabeta, 2015.

Pio, Eunike Anggie dan Greis Sendow,"Pengaruh Gaya Kepemimpinan Visioner, Kompensasi Tidak Langsung dan Penempatan Kerja Terhadap Kinerja Pegawai di Sekretariat Daerah Kabupaten Minahasa Tenggara," Jurnal EMBA, Vol3, No3, Sept. 2015, hal 1140-1150. Fakultas Ekonomi dan Bisnis, Jurusan Manajemen Universitas Sam Ratulangi, 2015.

Prawirosentono,"Manajemen Sumber Daya Manausia, Kebijakan Kinerja Karyawan. BPFE," Yogyakarta, 2016.

Robbins,"Prilaku Organisasi," Jakarta :Salemba, 2013.

Salleh Fauzilah,"Motivation And Job Performance Among State Government Employees In The East Coast," Jurnal Manajemen, ISSN 2302-0199. Fakultas Ekonomi Universitas Syiah Kuala, 2015.

Sedarmayanti,"Manajemen Sumber Daya Manusia, Reformasi Birokrasi, dan Manajemen Pegawai Negeri Sipil," Bandung :RefikaAditama, 2015.

Simanjuntak, J. Payaman,"Manajemen \& Evaluasi Kinerja," FEUI, 2013.

Sugiyono,"Metode Penelitian Kuantitatif, Kualitatif, dan R\&D," Bandung: ALFABETA, 2017.

Sunyoto, D.,"Manajemen Sumber Daya Manusia, "Yogyakarta :CAPS, 2014.

Suwatno,"Manajemen Sumber Daya Manusia," Jakarta: Erlangga, 2014.

Tilaar,.A.R.,"Perubahan Sosial dan Pendidikan: Pengantar Pedagogik Transformatif Untuk Indonesia," Jakarta: PT. Grasindo, 2014.

Wibowo,"Manajemen Kinerja," Edisi keempat, Rajawali Pers, Jakarta, 2013.

Wibowo , Dofa Ariska Wibowo,"Pengaruh Lingkungan Kerja, Disiplin Kerja dan Motivasi terhadap Kinerja Karyawan Indomaret di Semarang," Jurnal EMBA, Vol3, No3, Sept. 2015, hal 1140-1150. Fakultas Ekonomi dan Bisnis, Jurusan Manajemen Universitas Sam Ratulangi, 2015. 